\title{
Coloristic Properties of Piano Music Texture in Nikolai Medtner's Works
}

\author{
Vladimir V. Budnikov* \\ Khabarovsk State Institute of Culture \\ 112 Krasnorechenskaia Str., Khabarovsk, 680045, Russia
}

Received 04.02.2016, received in revised form 28.02.2016, accepted 12.04.2016

This article focuses on the research of colour as applied to N. Medtner's piano works. It discusses the composer's views on brilliance of colour, "sonority" (звучность) of music and texture as one of its most important means of expression. It is proved that colour interpretation of piano music texture in Medtner's works differs from the views on the colour embodied in the impressionists' music. Thus, that formed an opinion about "scarce colours", colour insufficiency of Medtner's musical compositions. Basing on the analysis of Medtner's works, the author changes the existing point of view by showing the dependence of specific colour of Medtner's works' texture on this original composer's rich, artistic and figurative system of music, thus actualizing the need for in-depth research of semantic contexts of his artistic images for the formation of the tradition of Medtner's music performance..

Keywords: music art, musical texture, colour of musical texture, timbre quality of piano texture.

DOI: 10.17516/1997-1370-2016-9-6-1443-1450.

Research area: art history.

The works by Nikolai Karlovich Medtner (1889-1951), a thinker, composer knowing his age, a master creating new contexts of art by means of sounds, are often chosen as a subject of research in modern art history (Zetel', 1981; Vasiuninskaia, 2014). However, even today his musical creative work can be defined as a scantily explored page in Russian music of the XX century. His heritage is mainly represented by piano music. Therefore, these are the pianistsperformers (пианисты-исполнители) who are responsible for careful "reading" of semantic contexts N. Medtner "put" in his works. They are responsible for "distinct" interpretation of his musical notation.
One of the essential features of the composer's style, in our opinion, is multicolour of his works' texture. A variety of colour is connected with extraordinarily imaginative richness of his works. The works often have a programme titles. For example, "The Mermaid", a fantastic improvisation, op. 2 No. 1, "The Magic Violin" op. 34 No. 1, "Procession of the Knights" op. 14 No. 2, "The Tale of the Bell" op. 20 No. 2, "WoodGoblin", a fairy tale, op. 34 No. 3, "The Tale of the Elves" op. 48 No. 2, etc. It's hard to imagine that such a variety of imaginative associations, Medtner refers to in the titles of his works, has no colour of expression in their texture. The composer's special attitude to the use of coloristic

(C) Siberian Federal University. All rights reserved

* Corresponding author E-mail address: vlboudnikov@mail.ru 
writing techniques should be termed "the critique of pure reason"1 in the sense that use of colour has some limiting framework necessarily determined by the artistic image. This, however, gives reasons to some researchers to think differently. V.G. Karatygin, a Soviet musical critic and composer, writes: "Medtner's music is a rocky, barren desert...", "Medtner's small "Fairy Tales" (c-moll, e-moll, b-moll, h-moll) lack a fabulous colour as he convulsively treads on one and the same place" (Karatygin, 1965, 68-69). "Medtner is a stone guest of Russian music" (Ibid., 266), Karatygin says, thus emphasizing the mineralogical (V. Karatygin's definition) element in the composer's musical imagery which is heavy and dense. The researcher is categorical in his evaluation of the composer's style: “... this is a wonderful and quite unpleasant feature of Medtner's "classicism". It is without a soul" (Ibid., 68-69).

Still, whereas V. Karatygin does not hear the colour in Medtner's works, Iu. Engel (Russian musical critic and composer) hears a principled external "tarnish" associated with restraint of the statement: “... in our time colours and colouring are at the center of musical expression, whereas they are just in the background in Medtner's pieces..." (Engel', 1971, 371). In his reviews on Medtner's concert Engel is fair and very precise: "There is no shade of idle talk and posing either in music or in performing it" (Ibid., 309).

Thus, a double impression on Medtner as a music colorist was formed among his contemporaries. On the one hand, he creates the richest figurative content; on the other hand, he does it with "scanty" expressive colours. To understand this contradiction it is necessary to consider the composer's views on texture, understand its features. Unlike many other composers, Medtner presented his conception of music in his work "The Muse and the Fashion". The metaphysical system, proposed by Medtner, reveals a great painter, thinker and philosopher in him.

The view on the texture of N. Medtner's piano works in the aspect of colour, stated in this article, is relevant for several reasons. Firstly, the research can contribute to the refutation of the view on scarce colours in his music that rooted in musicology. This view was expressed by N. Miaskovsky and V. Karatygin in their time. Thereby they formulated a one-sided opinion for the course of many decades. Secondly, such an important expressive tool as texture is largely formed by performing a piece of art. After all, not all the composers write everything in the notation-graphical text. They "subcontract" a professional performer to complete a music image. It is a performer who must correctly and fully decipher the signs that refer to various meanings, including the signs of colour. Thus, the issue of colour interpretation of Medtner's piano music serves the idea of Medtner's performing style which needs to be updated at the present stage of the piano art development. In the absence of formed performing traditions in Medtner's music, which is classified as rarely performed, it is necessary not only to popularize it, but give an inquisitive and impartial research of his creative work ${ }^{2}$.

And finally, contemporary artistic practice results in the change of research ideas about musical texture (Snitkova, 1991; Shaviner, 1982). A search for the XX century creators in the field of composer's techniques, special methods of sound production, etc. significantly expands colouristic possibilities of music texture. Whereas texture was previously understood as "a collection of presentation means", in L. Mazel's, V. Zuckerman's, Iu. Tiulin's, M. Shaviner' works it is viewed as "an artistic organization of all the components of music texture" (Shaviner, 1982, 11). Other means of music expression - harmony, timbre - undoubtedly have their colouristic 
possibilities, but it is in piano music in which the colour is largely a property of texture. Developing the contemporary researchers' ideas about music texture, it can be assumed that texture as a spatial-acoustic category captures the modes of relationship between the elements within the sound pattern.

As for the brilliance of colours, specific colour of texture of Medtner's works is rooted, in our opinion, in the rich inner life of his artistic images. However, as for Medtner's view of the role of colour, this seemingly "external" layer of the sound pattern, it is different from a common view on it in its general semantic field. His colours do not solve an ornamental task. For him, the richness of texture is a luxury that distracts from the perception of meaning. Medtner's sound pattern, however, is truly original. It comes from internal problems of an artistic idea and contributes to the comprehension of the expressive possibilities and the semantic potential of the basic components of musical speech - harmony, melody, form.

A well-known judgment on lack of colours in Medtner's music made by N. Miaskovsky (Miaskovskii, 1981, 22), a Russian composer of the XX century and Medtner's contemporary, is opposed to its obvious, "lying on the surface" understanding. In fact, it does not refute Medtner's opinion on it but focuses it. Medtner does not suppose brilliance of colour - in the usual sense of the word - in the piano texture of his works. But, nevertheless, his works are recognized as highly colourful. To figure this problem out, it is worth while clarifying what each of these composers mean by the brilliance of colours.

Miaskovsky-critic explicitly states that Medtner's music lacks colours. “...My attraction to Medtner results from the following properties of his music: richness of texture which is unusual even in our time; external restraint, self-depth of expression, the ones that can't make his works boring, and, finally, - scarce colours" (Ibid., 22).

Right after the words "the main reason for my aspirations to colourless Medtner is that the lack of brilliance of colour in his music is naturally compensated with greater compactness, depth and kinetic tension of his thought as well as in the corresponding complication or refinement of the general texture of his works" Miaskovsky explains that "this intensifies the process of mental perception, and excessive colorful luxury (italics. - V. B.) neither scatters nor blunts mental impressionability" (Ibid., 23).

Thus, Miaskovsky, a great expert and lover of Medtner's creativity, still admits the presence of colour in the texture of his music. However, its presence is not measured by the concept of excessiveness. In other words, there is the colour, but within moderate limits. Medtner's principle of insufficient colour contrasts the impressionists' principle of excessiveness of colour. The lack of colour in Medtner's piano works correlates with the category of poverty of form in Mozart's works - there is nothing excessive in them.

Further Miaskovsky states it differently: "As if struggling Medtner avoids broad strokes, stains, air, vastness - painting, in brief. I deliberately said 'avoids', because he certainly can compose... in bright colours: it may be op. 1 Stimmungsbilder, op.17-E-dur novel, h-moll tale, op. 20 or many romances (at least "Meeresstille", "Winter Evening"), etc. ..., there are abundantly scattered pictorial ideas everywhere, the ideas being interestingly and unusually implemented" (Ibid., 26).

Thus, Miaskovsky is inconsistent in his opinion. Convincingly bringing the entire issue of Medtner's colour to the graphic quality of his music, he still does not deny the colour of some works. Even claiming his main idea about the graphic quality of Medtner's music and supporting it with the conclusions about the 
predominance of linearity in the texture of his works, he, nevertheless, cannot regard the work of this "earnest" fighter for the purity of the basics of art (and colour, in particular) from a broader perspective.

At a wider look Medtner is a master, who uses different manners of writing - graphic, pastel, watercolors, and painting - in accordance with an artistic idea. Medtner himself considered it to be completely inappropriate to transfer the concepts of visual art to the sphere of music: “... we dare not approach it (music - V. B.] with the criteria of painting..." (Medtner, 1935, p. 57). However, in research practice such borrowing is not only familiar (as, to the point, the very notion of the concept texture) but also productive for the musical and coloristic phenomena analysis.

Is not it this inner doubt, expressed in vagueness of colouristic evaluation of Medtner's creativity, that paradoxically makes Miaskovsky's statements closer to the composer's ones? That is, Miaskovsky intuitively suggests that Medtner does not take colour "seriously", he is critical of the use of colour in the composer's work. 'Critically' means sparingly, thoughtfully, to the extent which is necessary for a certain artistic image.

"Sonority(Dynamics, Color, SoundQuality)" part in his book "The Muse and the Fashion" contains the composer's basic considerations about the colour and its associations with dynamics and sound quality as such. The composer's compelling and systematic view on the place of colour in the semantic whole is also traced. Medtner dwells on the four values of the sonority concept. And this is very important.

The first value: "sonority itself as sound quality appeals to our auditory sense, to the taste of our external hearing, which in itself can only increase or weaken our pleasure from the object qualities but cannot determine its nature or value" (Ibid., 55) . That is colour refers to the sound qualities and, therefore, does not carry the semantic load.

The second value, at first glance, is totally mediated but extremely subtly linked to the process of music performance. Medtner writes that "in its connection with the music distribution on different instruments (instrumentation) the sonority concept is already getting closer to the concept of performance" (Ibid., 56). In other words, sonority suggests textural statement of being. Sonority is formed of a mix of sounds belonging to different colours (sonorities). And further, quite close to the colour problems of pianism: "performing the music is the most appropriate distribution of sonority" (Ibid., p. 56). Medtner argues that the performer's skill is the ability to distribute sonority (the performers say about a dynamic stratification of texture) so that the sound becomes efficient, that is in accordance with an artistic image subordinate to the idea.

The third value defines sonority as the sound quality that can directly be termed the colour. Medtner refers it strictly to the art of instrumentation: "like colour, sonority always implies the only instrumentation. Modern listeners very often refer dazzling harmony, modulation or saturated counterpoint to a sound colouring, that is, they cause exclamations "what sonority!"... “what colouring!"... “what dynamics!".. (Ibid., 5657). Thus, according to Medtner, colour uniquely "belongs" to the symphony orchestra and its instruments. Yet, the composer does not explain whether it is possible to instrument the piano sonority with the expressive possibilities of the piano itself, and whether the piano texture can be analyzed in terms of instrumentation principles. It is significant that the dynamics is mentioned together with the sonority, as it is the main instrument of timbre formation on the piano.

And, finally, determining the fourth value, the composer generalizes the concept 
of sonority to the concept of phonism. Medtner regards the piano sonority as a single category the Impressionists (Debussy) considered to be a dominant one. "Absolute sonority is musical impressionism" (Ibid., p. 57). As a key expressive tool, it is the main content of impressionistic writing. But sonority has no meaning, so, impressionism, according to Medtner, "is flirting with chaos".

So, Medtner puts four values in the concept of sonority (colour): 1. Sonority as the sound quality in general, 2. Sonority as a method of dynamic distribution of sounds in the texture, 3. Sonority as a set of real orchestral timbres, 4. Sonority as phonism.

Does Medtner's dogmatic rhetoric cause an idea expressed by Miaskovsky, the idea being about the graphic quality of the texture? The fact is that Medtner does not regard the colour together with the basic meanings of music, in principle. He says that colour, that is sonority, is" at the service of musical elements" (Ibid., p. 55). This is not a property of music at all. The colour is subordinated to the main element, the harmony. "Sonority can never become a theme. Whereas other elements appeal to our spirit, soul, feelings, and thoughts, sonority as it is, as the sound quality appeals to our auditory sense" (Ibid., p. 55).

Medtner does not misuse the colour, yet it does not mean that he is closer to graphics. Still, is there any graphic quality in his works? In fact, the presence of logically organized musical lines in any place of the texture does not weaken the phonic properties of the latter. The fact is that the colour cannot be created by the scattered non-consistent - texture elements, that is by those pieces that provide the only possibility of colour without participating in the process of conceptualization ${ }^{3}$.

Miaskovsky also attributes several meanings to the concept of scarce colours in
Medtner's works: 1) scarce colours as lack of brilliance of colours, 2) scarce colours as colour insufficiency, 3) scarce colours as blackness, dreariness and stiffness of harmony, 4) scarce colours as graphic quality, i.e. a combination of scarce colours with a line, pattern. The following statement by Miaskovsky is indicative here: "The outlines of his melodies are always clear and distinct; the patterns of figurations, side voices are carefully tuned and subject to some strongly conducted idea; duration of harmonic beats is probably reduced almost to the limit of artistic reasonability (scarce colours and lack of colour being the result of these); harmonic locations differ in contiguity and certain doubling that result in thickness - blackness of harmony (this explains its certain dreariness and stiffness); rhythmics, that is recognized as rich, is also reduced to fragments; and, finally, the contrapuntal texture is very rich; this is how Medtner as if struggling avoids broad strokes, stains, air, vastness - painting, in a word" (Miaskovskii, 26).

His statement about one of the causes of such scarce colours seems paradoxical. Miaskovsky explains the impossibility of colour by the fact that "duration of harmonic beats is probably reduced almost to the limit of artistic reasonability". That is, a concentrated change of harmonies proves not a manifestation of a kind of expressive sonority, which is almost point set, but a mere thickening of colour to blackness. What does the limit of artistic reasonability mean in this context? Does not a very frequent change of harmonies give reason to speak about non-artistry? It is possible to assume that only one chromatic cluster has real blackness.

In painting as a form of art the concepts of tone and colour are separated. The tone is a black-and-white spectrum (more clearly: bright - dark), colour is a red-yellow-greenblue spectrum (many-coloured). Tonal 
relationships dominate in graphics, whereas colour ones dominate in painting (although the most complex combinations - watercolour, for example, or graphics with the elements of painting, etc. - are possible in modern fine arts.

Musicians do not use the borrowed concepts of tone and colour as precisely and accurately as artists. On the contrary. The principle of brilliance of colour in music art fits the concept of tone, keynote, and chord patterns (it is important to mention that in the Baroque era a certain emotional colouring corresponds to a particular keynote). As for the principle of graphics, it corresponds to the concept of the melodic line, which, in our opinion, narrows the associative field, depletes the graphic quality to the line, without taking the intensity of the stroke, push, games of light and shade into account. The principle of graphics seems to be associated with the dynamics (quieterlouder) as well, the dynamics being a correlate of tonal relationships in visual art (darkerlighter).

In music, along with the musical texture that does not need the "picturesqueness", there are pure "picturesque" opuses. For example, J.S. Bach in his "The Art of Fugue" intentionally "ignores" a timbre (instrumental) solution to enhance the perception of inner meaning. The music of impressionism, on the contrary, affects the perception of timbre mostly with a timbre "tactile" side, weakening the perception of the depth of feelings (colour as a feeling).

Therefore, the concepts of timbre and colour in music can be different. It is conventional to correlate timbre with the concept of the sound quality of a specific source: a human voice, an instrument. Timbre is a mere feature. However, regarding the texture it will be more correct to use the concept of timbral quality. As the principle of texture timbre formation it exists by analogy with the concept of local colour in fine arts. Local colour is a complex of tone and colour, a sum of all the nuances. It is timbral quality that is colour in music, in fact.

Zetel' refers to a great guess made by Miaskovsky-critic in 1913: "The internal need for details aroused the critic's associations with Durer's and Rembrandt's art, the painters whom he saw Medtner's 'genetic' link with" (Zetel', 1981, 75).

Picturesque analogy is inappropriate for Medtner who reasoned this in "The Muse and the Fashion". “"Impressionism” in painting requires distance, but for musical perception the distance has no influence on the content and semantic quality of sounds, but only on their greater or lesser audibility..." (Medtner, 1935, 57]. Still, Medtner denies the brilliance of colour only in its extreme value - an impressionistic, self-sufficient one.

Medtner is also right because he denies what he claims, and namely: the brilliance of colour in music is created by greater or lesser audibility of sounds, in fact - by dynamics which is run by a performer. Medtner makes it clear that the art of performing returns to the sound pattern something that is not reflected in the text but what the composer means, it returns a characteristic component of colour, inherent to it, - dynamic stratification of texture.

Summing up, it is worth while noting that the knowledge of N. Medtner's music requires thoughtful analysis. At the present time, the narrow grammatical approach to the performing analysis of the text is not enough. A broader perspective on the author's context, including a colour one, which reveals the meaning of textural types in Medtner's works and, ultimately, the depth of figurative content, is necessary. 
This definition appeared by analogy with Kant's famous work "The Critique of Pure Reason" in which he discourses upon the need for special science with the aim to become "the critique of pure reason, its usefulness in speculation would really be only negative; it would not enlarge our reason's scope, but would purify it, keeping it free from errors - which itself is a considerable achievement" (Kant, 1993, 44).

2 N. Cherepnin, A. Grechaninov, I. Akhron, I. Dobrovein, emigrant composers, have been waiting for their "return" to the bosom of Russian musical culture. Their creative work, retaining the images of pre-revolutionary Russia, will fairly join the integrity of the musical memory of the Russian culture.

3 As in the stylistics of pointillist music, as a rule.

\section{References}

Engel', Iu.D. (1971). Glazami sovremennika. Izbrannye stat'i o russkoi muzyke 1898 - 1918 [Through the eyes of the contemporary. Selected articles on Russian music of 1898 - 1918]. Moscow, Sovetskii kompozitor.

Kant, I. (1993). Kritika chistogo razuma [The Critique of Pure Reason]. St.Petersburg, TAIMAUT, 478 p.

Karatygin, V.G. (1965). Izbrannye stat'i [Selected Articles]. Moscow, Leningrad, Muzyka, 352 p. Medtner, N.K. (1935). Muza i moda [The Muse and the Fashion]. Paris, YMCA-PRESS, 158 p.

Miaskovskii, N.Ia. (1981). N.K. Metner. Vpechatleniia ot ego tvorcheskogo oblika [N.K. Medtner. Impressions from his Creative Image]. Medtner, N.K. Vospominaniia. Stat'i. Materialy [Metner, N.K. Reminiscences. Articles. Materials]. St.Petersburg, Sovetskii kompozitor.

Shaviner, M.A. (1982). Nekotorye osobennosti faktury fortepiannykh proizvedenii I. Bramsa [Some Features of the Music of I. Brams's Piano Pieces]. Problemy muzykal'noi faktury. Vyp. 59 [Issues of Music Texture. Issue 59]. Moscow, GMPI im. Gnesinykh, $140 \mathrm{p}$.

Skrebkova-Filatova, M.S. (1982). O formoobrazuiushchikh funktsiiakh muzykal'noi faktury [On Form-Organizing Functions of Music Texture]. Problemy muzykal'noi faktury. Vyp. 59 [Issues of Music Texture. Issue 59]. Moscow, GMPI im. Gnesinykh, 140 p.

Snitkova, I. (1991). Zvukovoi material sovremennoi muzyki i nekotorye aspekty teorii faktury [Sound Material of Contemporary Music and Some Aspects of the Theory of Music Texture]. Faktura $v$ sisteme muzykal'no-vyrazitel'nysh sredstv [The Texture in the System of Musical Expressive Means]. Krasnoyarsk, Publishing House of Krasnoyarsk State University, 192 p.

Vasiuninskaia, E.A. (2014). N.K. Metner: lichnost', vzgliady, stil' (Ispolnenie muzyki Metnera: analiticheskie etiudy) [N.K. Medtner: Personality, Ideas, Style (Medtner's Music Performance: Analytical etudes)]. St. Petersburg: Kompozitor - Sankt-Petersburg, 192 p.

Zetel', I. (1981). N.K. Metner - a pianist [N.K. Medtner as a pianist]. Moscow, Muzyka. 


\title{
Колористические свойства фортепианной фактуры \\ в произведениях Николая Метнера
}

В.В. Будников

Хабаровский государственный институт культурь Россия, 680045, Хабаровск, ул. Краснореченская, 112

\begin{abstract}
Данная статья посвящена исследованию колорита применительно к фортепианным произведениям Н. Метнера. В статье рассматриваются взгляды самого композитора на красочность, «звучность» музыки и одного из важнейтих её выразительных средств - фактуры. Показано, что колористическая трактовка фортепианной фактуры в произведениях Метнера отличается от представлений о колорите, получивиих воплощение в музыке импрессионистов, что и сформировало мнение о «некрасочности», колористической недостаточности его музыкальных сочинений. Автор статьи на основе анализа работ Метнера решает задачу по изменению сложивиейся точки зрения, показывает обусловленность особой колористичности фактуры его произведений богатством, насыщенностью художественно-образного строя музыки столь самобытного композитора, актуализирует необходимость углублённого изучения смысловых контекстов его художественных образов для формирования исполнительской традиции музыки Метнера.
\end{abstract}

Ключевые слова: музыкальное искусство, музыкальная фактура, колористичность музыкальной фактуры, тембральность фортепианной фактуры.

Научная специальность: 17.00.00-искусствоведение. 